\title{
EVALUATION OF SCORPION STING INCIDENCE IN TURKEY
}

\author{
OZKAN O. (1), UZUN R. (1), ADIGUZEL S. (1),
} CESARETLI Y. (1), ERTEK M. (1)

(1) Refik Saydam Hygiene Center, Ankara, Turkey.

ABSTRACT: Scorpion stings are common in Turkey due to its geographical location, climate and socioeconomic structure. Scorpion envenomation cases are a considerable public health problem in all regions of the country. Important healththreatening scorpions in Turkey are Androctonus crassicauda, Leiurus quinquestriatus, Mesobuthus gibbosus and M. eupeus, all of which belong to the Buthidae family. They are described to be potentially dangerous to humans. So far, there is no study about scorpion sting incidence covering all geographical regions of Turkey; therefore, in this study, we analyzed the frequency of scorpion sting cases in the country. A total of 24,261 scorpion sting cases were reported during 2005. Most of which (about 80\%) occurred in the Southeastern Anatolia (30.4\%), Mediterranean Sea (24.9\%) and Aegean regions (23.5\%), where medically important scorpion species are found. The sting cases mostly occurred during the summer period. Our results suggest that scorpion stings are an important problem in Turkey. This simple descriptive study will help develop interventions to prevent scorpion stings, which should take local sting cases into consideration.

KEY WORDS: scorpion sting, Turkey, epidemiology.

CONFLICTS OF INTEREST: There is no conflict.

\section{CORRESPONDENCE TO:}

OZCAN OZKAN, Refik Saydam Hygiene Center, 06100 Ankara, Turkey. Phone: 00 9031249821 50/135. Email: ozcanozkan 62@hotmail.com. 


\section{INTRODUCTION}

Scorpions are arthropods of 13 to $220 \mathrm{~mm}$ length; thus, they are easily recognizable because of their morphological structures (31). All scorpions are venomous, but only fifty of them are potentially lethal to humans $(19,28)$. Scorpion stings can be lifethreatening, especially for children and older individuals that may suffer from respiratory and/or cardiovascular diseases in the future $(6,13,18,25)$. Therefore, they are considered medically important arthropods since they cause envenomation by stinging humans, most of the times, to protect themselves $(13,30,32)$. Medically important species belong to the genera Buthus, Parabuthus, Mesobuthus, Tityus, Leiurus, Androctonus, and Centruroides from the Buthidae family (5, 19, 35, 39). Among these, the most important species are $T$. serrulatus, $T$. bahiensis, $T$. stigmurus and $T$. trivittatus in South America; $(2,8,33,36)$; $C$. suffusus, $C$. infamatus, C. limpidus, and C. sculpturatus in Mexico $(9,11,28)$; L. quinquestriatus, A. crassicauda, A. mauretanicus, $A$. australis, $A$. amoreuxi, and $B$. occitanus in the Middle East and North African countries (13, 14, 16-18, 34, 40); P. granulatus and $P$. transvaalicus in South African countries (7, 27); and M. tamulus and Palamneus swammerdami in India $(6,25)$.

Scorpions and scorpion sting cases are common in Turkey due to its geographical location, climate and socioeconomic structure $(30,31)$. In Turkey, A. crassicauda, $L$. quinquestriatus, $M$. gibbosus, and $M$. eupeus have been considered dangerous to humans $(6,12,29-32)$.

In spite of the epidemiological and clinical data limitations, this simple descriptive study will help develop interventions to prevent scorpion stings, which should take into consideration local sting cases. In this study, we analyzed data based on the number of scorpion stings associated with previously designed studies on scorpion sting cases in Turkey during the year of 2005, aimed at providing data to develop national policies and activities in risky regions of Turkey.

\section{MATERIALS AND METHODS}

\section{Location of Turkey}

Turkey $\left(36^{\circ}-42^{\circ} \mathrm{W} ; 26^{\circ}-45^{\circ} \mathrm{E}\right)$, with a total area of $77945 \mathrm{~km}^{2}$, lies between Europe and Asia and is surrounded by the Black Sea, Bulgaria and Greece on the north, the Aegean Sea on the west, the Mediterranean Sea, Syria and Iraq on the south, Iran on the east, and Armenia and Georgia on the northeast (The Turkish State 
Meteorological Service). There are a total of 81 provinces in the Southeastern Anatolia, Mediterranean Sea, Aegean, Central Anatolia, East Anatolia, Marmara, and Black Sea regions of Turkey.

\section{Data on Scorpion Sting}

Data on scorpion stings included 81 cities from the seven regions of Turkey. We used data of scorpion stings on humans, which have been reported by provincial, local hospitals or primary health centers to the Ministry of Health during 2005.

\section{Population Data}

We obtained population data from the 2000 census of Turkish Statistical Institute.

\section{Statistical Analysis}

All data were analyzed using SPSS software and the Pearson's Chi-Square method. Results were considered significant when the $p$ value was less than 0.01 .

\section{RESULTS}

Our study analyzed 24,261 scorpion sting cases reported by health centers to the Ministry of Health during 2005. No data on scorpion sting was provided by the following nine $(11 \%)$ provinces: Agri, Ardahan, Balikesir, Bartin, Bayburt, Bolu, Canakkale, Istanbul and Manisa (Figure 1), whereas data were obtained from 72 $(89 \%)$ provinces. Sting cases occurred in all regions. The largest numbers of cases were reported in the Southeastern Anatolia region (30.4\%; Figure 2), followed by the Mediterranean Sea region (24.9\%; Figure 3), the Aegean region (23.5\%; Figure 4), the Central Anatolia region (11.4\%) and the East Anatolia region (5.5\%).

No death due to scorpion stings was reported during the study period. The ratio between scorpion stings and populations in the regions (Table 1) was statistically significant $(p<0.001)$. The highest morbidity ratios were determined in the Southeastern Anatolia and Mediterranean Sea regions, whereas the lowest morbidity ratios were determined in the Black Sea and Marmara regions of Turkey (Table 1).

Seasonal distribution of the scorpion sting cases is shown in Figure 5. In the summer period, $12,985(53.5 \%)$ out of 24,621 sting cases were reported; the following seasonal distribution was observed: autumn (22.1\%), spring (19.9\%), and winter (4.5\%). In the Marmara region, most sting cases were seen in the spring, whereas in 
other regions it was noticed in the summer period. Analysis of data showed that scorpion sting cases increased during the spring and summer seasons in the Southeastern Anatolia, Aegean and East Anatolia regions. The cases increased during the summer and autumn periods in the Mediterranean and Central Anatolia regions (Figure 5). There was a statistically significant association between scorpion sting incidence and seasons $(p<0.001)$.

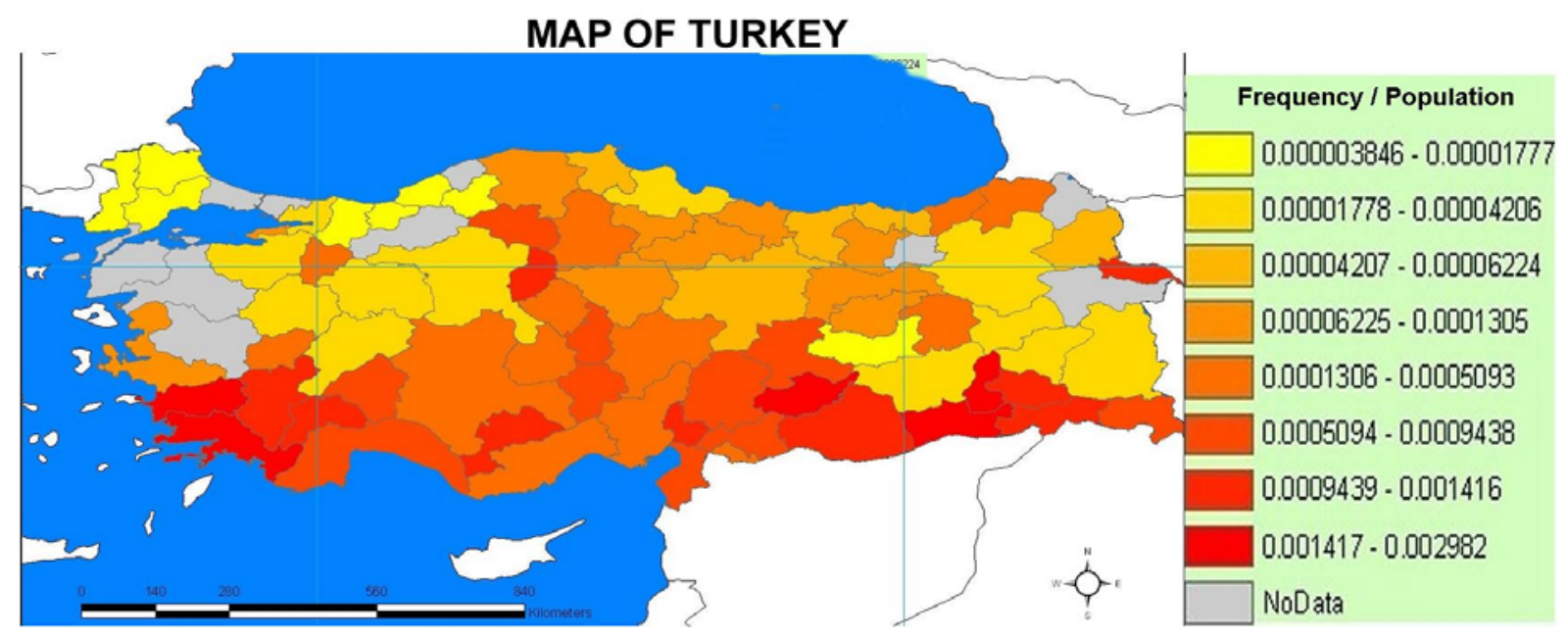

Figure 1. Distribution of scorpion stings according to the provinces of Turkey. The risk of scorpionism was assessed based on the sting frequency/population ratio.
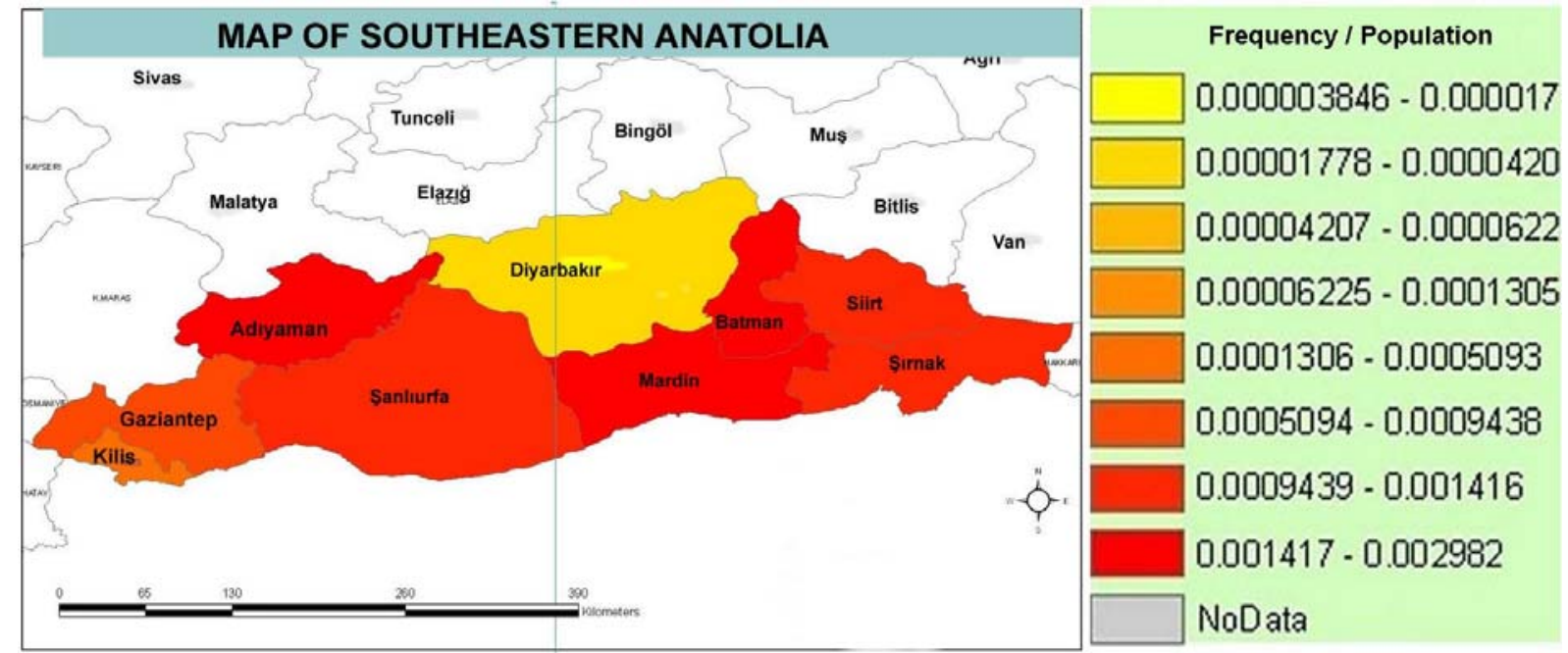

Figure 2. The Southeastern Anatolia region with its provinces according to occurrence of the highest morbidity ratios. 


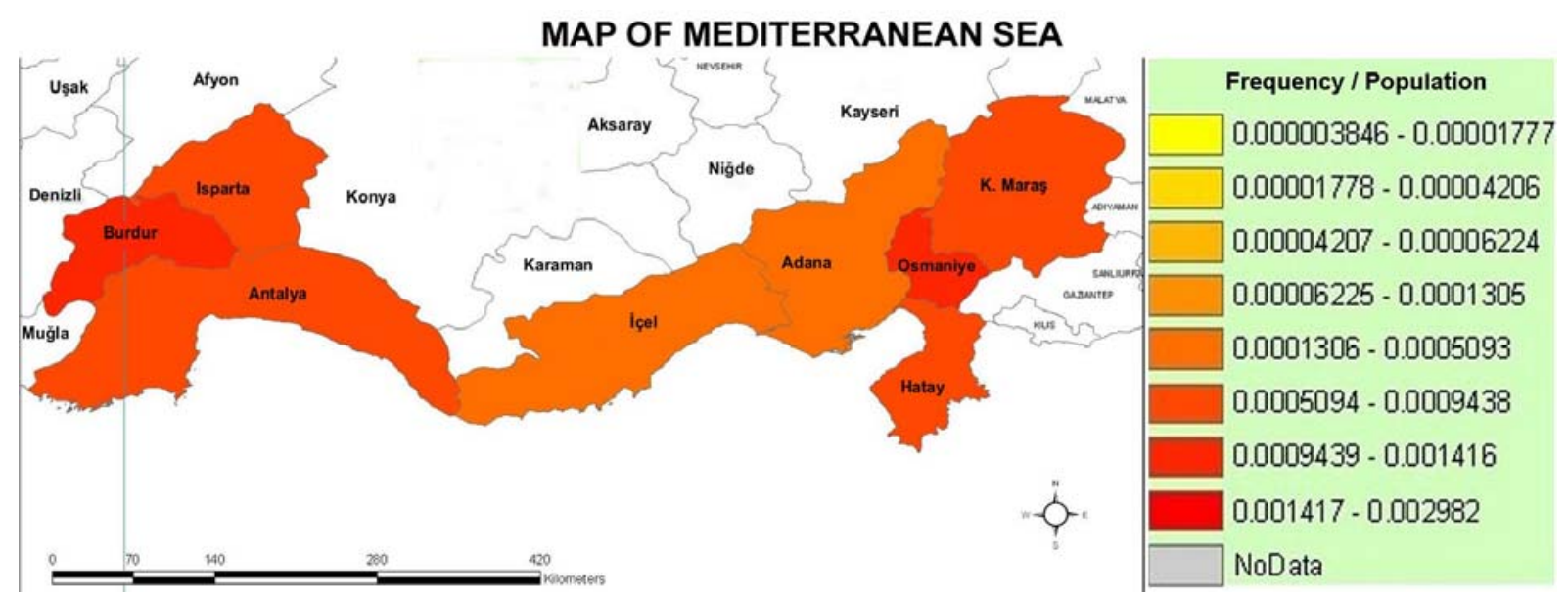

Figure 3. The majority of scorpion stings were seen in Antalya, Kahramanmaras, Icel, and Hatay Provinces of the Mediterranean Sea region.

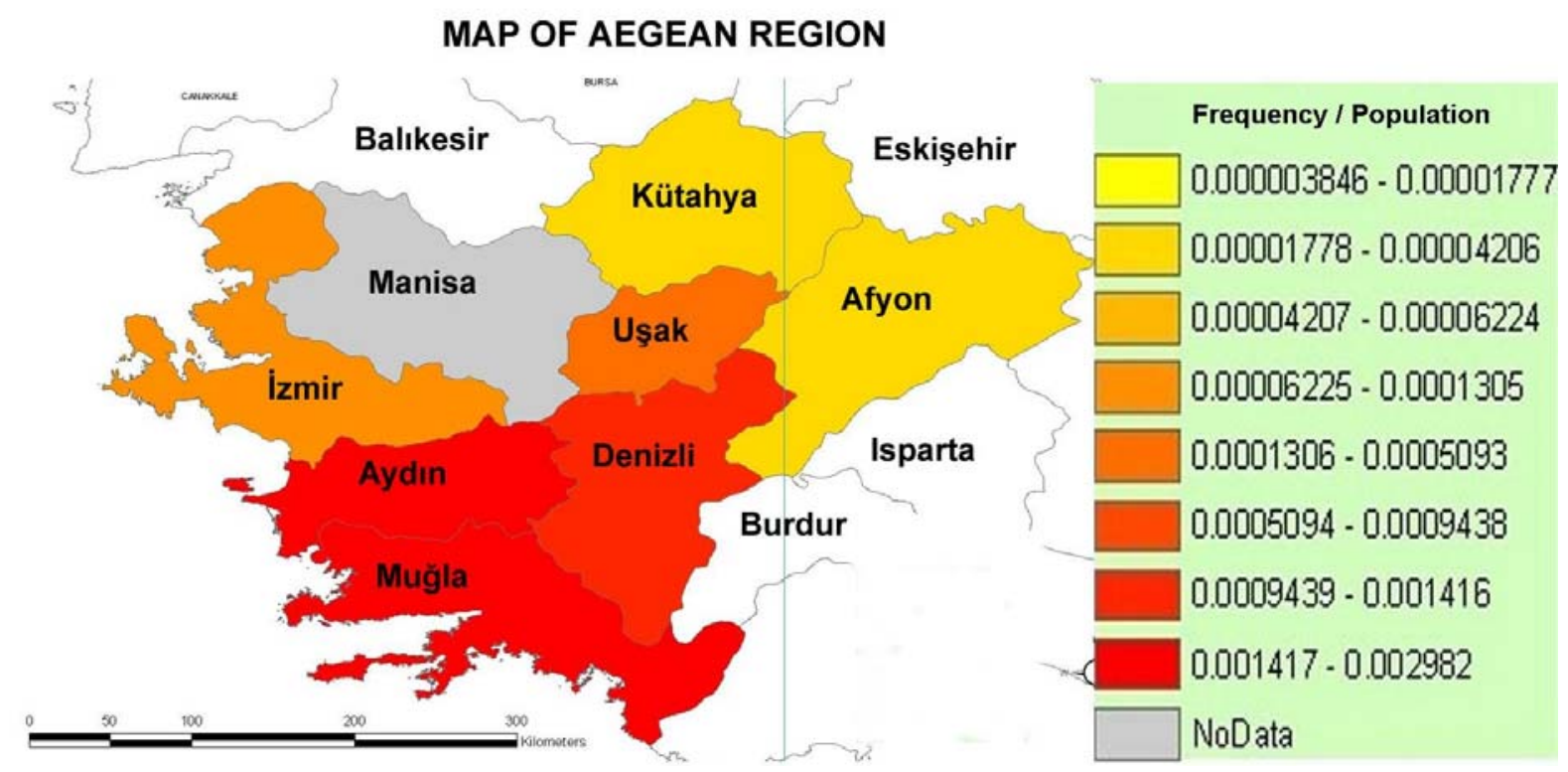

Figure 4. Scorpion stings are responsible for significant morbidity in Mugla, Aydın and Denizli Provinces of the Aegean region. 


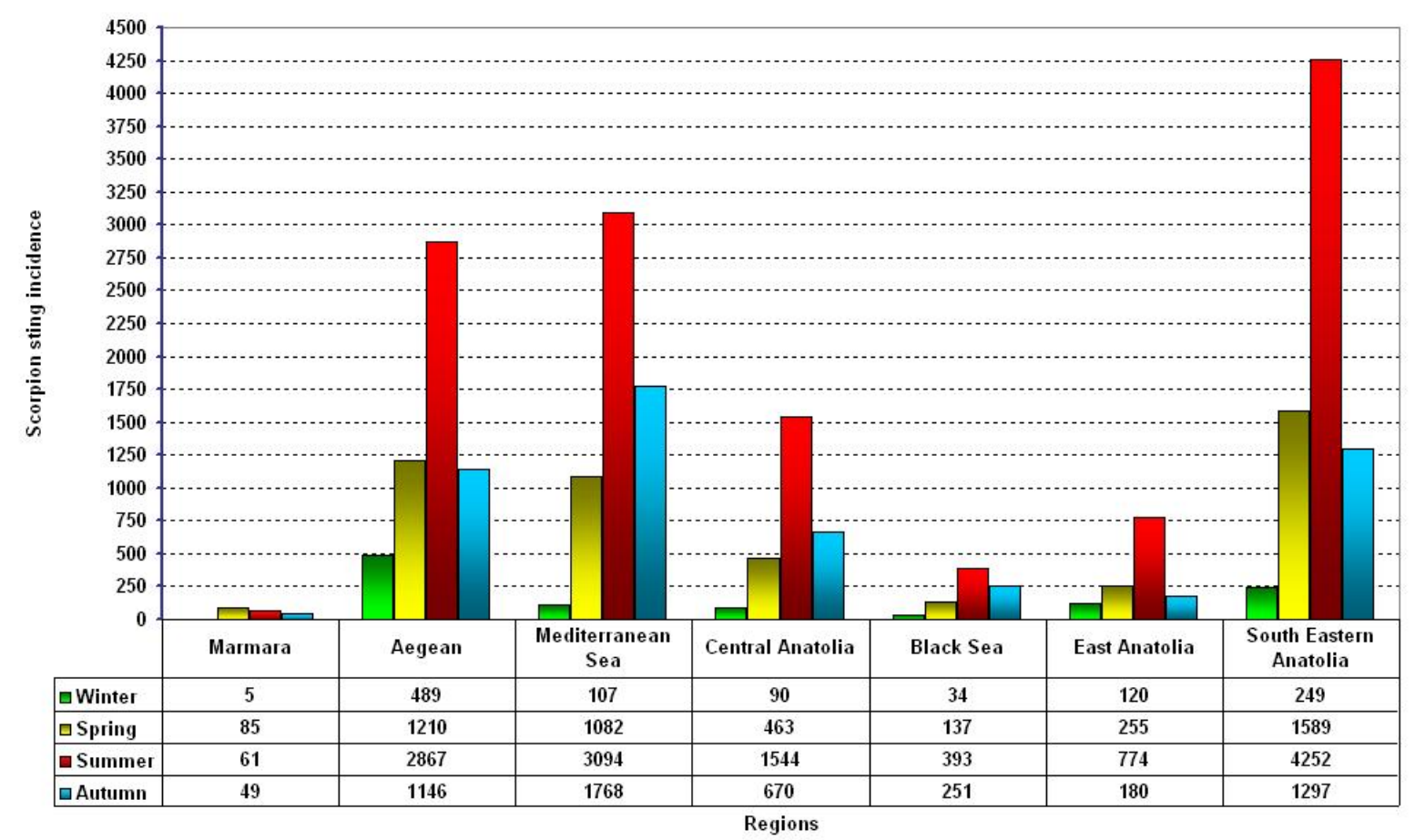

Figure 5. Seasonal distribution of the scorpion stings in Turkey. Except for the Marmara region, most stings were seen in the summer period.

Table 1. Morbidity ratios according to the regions of Turkey.

\begin{tabular}{lcccc}
\hline Regions & Number of stings & $\%$ & Morbidity (\%o) & $P$ \\
\hline Southeastern Anatolia & 7387 & 30.4 & 1.1 & $<0.001$ \\
Mediterranean Sea & 6051 & 24.9 & 0.7 & $<0.001$ \\
Aegean & 5712 & 23.5 & 0.6 & $<0.001$ \\
Central Anatolia & 767 & 11.4 & 0.2 & $<0.001$ \\
East Anatolia & 1329 & 5.5 & 0.2 & $<0.001$ \\
Black Sea & 815 & 3.5 & 0.01 & $<0.001$ \\
Marmara & 200 & 0.8 & 0.01 & $<0.001$ \\
\hline Turkey & $\mathbf{2 4 2 6 1}$ & $\mathbf{1 0 0}$ & $\mathbf{0 . 3}$ & $<0.001$ \\
\hline
\end{tabular}

\section{DISCUSSION}

In Turkey, fifteen species belonging to four families - Buthidae, Euscorpiidae, luridae, and Scorpionidae - have been identified so far $(12,21,31,41,42)$. The most venomous species appear to be $L$. quinquestriatus and $A$. crassicauda from the family Buthidae $(4,30,37)$. In this family, $M$. eupesus and $M$. gibbosus are also 
described as potentially dangerous scorpion species to humans $(7,32,35,43)$. On the other hand, no data has been found on the toxicity of M. caucasicus and $M$. nigrocinctus scorpions $(12,23)$.

Scorpion stings can result in severe envenomations that constitute an important public health problem in Turkey $(4,7,37)$. Morbidity and mortality due to scorpion stings have been previously reported in different parts of Turkey $(1,4,10,20,24,26$, $30,32,37,38)$. However, there is no study about the general scorpion sting incidence covering all geographical regions of Turkey.

In Southeastern Anatolia, L. quinquestriatus, A. crassicauda, M. eupeus, M. caucasicus, M. nigrocinctus and Hottentotta saulcyi from the Buthidae family were found (12, 15, 21-23). Soker and Haspolat (37) reported 64 scorpion sting cases in children admitted to the Pediatric Emergency Department in Dicle University Hospital from Diyarbakir, Mardin, Sirnak, Batman and Siirt Provinces of the southeastern part of Turkey during 1995-1999. The authors also recorded eight lethal cases (12.5\%) which were due to cardio and respiratory failure during the first $24 \mathrm{~h}$ of hospitalization. Ozkan et al. (30) notified that in A. crassicauda toxicity cases, patients showed parasympathetic and local failures, which are characterized by pain, hyperemia and edema. Ozkan and Kat (31) recorded $152 \mathrm{M}$. eupeus sting cases in Sanlıurfa during six months and, in those cases, patients showed autonomic system as well as local failures, which were characterized by pain, hyperemia and edema. Adiguzel et al. (1) stated that child patients showed signs of local and autonomic nervous system failures but no lethality occurred in these cases.

Similarly to these clinical studies, in our study most of the scorpion stings $(30.4 \%)$ were seen in the Southeastern Anatolia region of Turkey. A larger number of scorpion stings were recorded in the provinces of Sanliurfa (22.6\%), Adiyaman (19.9\%), Mardin (18\%), Gaziantep (13.9\%), and Batman (13\%) than in the other provinces of this region (Figure 2). The current study indicates that scorpion stings are still a major public health problem in this region which has the most dangerous scorpion species.

Mesobuthus gibbosus is also a common species from the Aegean region of Central Anatolia to the middle of East Anatolia (12, 15, 21, 23, 31). In a study in the Aegean region, Suzek et al. (38) stated that 262 patients stung by scorpions (M. gibbosus) applied to the Emergency Service of the State Hospital of Mugla Province between 1999 and 2001. The patients (50.35\%) were hospitalized and treated by medical 
professionals with antivenom (81\%). On the other hand, the authors reported that two cases $(1.17 \%)$ resulted in death in 1999. Akcay et al. (3) investigated envenomation cases in Denizli including the retrospective five years and recorded that $1.5 \%$ of these cases were scorpionisms. Altinkaynak et al. (4) investigated 24 children stung by scorpions in Marmaris District of Mugla Province. They stated that the patients showed clinical symptoms like abdominal pain, muscle contractions, nausea, hypertension, hypotension, bradycardia, dyspnea, pulmonary edema, convulsion, and shock and reported $8.3 \%$ lethality due to cardio and respiratory failure. In the present study, scorpion stings were mostly seen in Mugla (37.3\%), Aydin (37\%), and Denizli (19\%) of the Aegean region, Turkey (Figure 4).

On the other hand, in a study in Antalya, a province of the Mediterranean Sea region, Dayar et al. (10) presented a case of a five-year-old girl that was stung by a scorpion and admitted to the hospital with generalized muscle contraction, pulmonary edema, tachypnea, serious arrhythmia, tachycardia, abnormal electrocardiography findings and increased cardiac enzymes. The authors notified that the patient died due to myocardial ischemia. In our investigation, analysis of scorpion sting data of the Mediterranean Sea region (Figure 3) showed that the majority of cases were notified in Antalya (30.5\%).

In one of the clinical studies in Central Anatolia, Kekec et al. (24) recorded that scorpion stings were the most common cases (43\%) in all animal-originated envenomation cases applied to the Medical School Department of the Emergency Service, Erciyes University of Kayseri, between January and December 1999. In our study, a larger number of scorpion sting cases were recorded in Konya and Kirikkale Provinces than in the other provinces of this region.

With regard to Eastern Anatolia, Karakurt and Kocak (20) reported two cases of children who suffered from myocarditis and pulmonary edema after scorpion stings in Malatya Province. In the current study, the majority of scorpion stings (49\%) were recorded in Malatya Province.

In a study in Trabzon Province of the Black Sea region, Mocan et al. (26) presented a case of a 28-year-old man admitted to the Faculty of Medicine, Black Sea Technical University, with a history of right leg pain, vomiting, diarrhea, agitation, restlessness, blurred vision, peripheral cyanosis, increased lachrymation and salivation, and oliguria following a scorpion sting which had occurred two days before. Thus, the authors suggested that scorpion stings should be added to the ever-growing list of 
causes of hemolytic-uremic syndrome. They also stated that Euscorpius carpaticus, E. germanus and E. italicus are known as nonlethal scorpion species in this region. Our analysis showed that scorpion sting cases were mostly seen in the provinces of Corum (28.7\%), Rize (15\%), Ordu (10\%) and Tokat (9.2\%) in this region.

Turkey has a subtropical, semi-arid climate with extreme temperatures. In the east, summers are hot and dry; winters are cold, rainy and snowy. Along the coastal area, the Mediterranean climate is dominant with long, hot, dry summers and short, mild, rainy winters. Rainfall shows great differences from one region to another in Turkey (www.meteor.gov.tr). Similarly, most scorpion sting cases were seen during the summer period in Brazil, Saudi Arabia, Egypt, Morocco and Iran (14, 16, 34, 36, 40) when compared to the other months, which agrees with the findings of our study. On the other hand, most sting cases were seen at spring time in the Marmara region. In the other regions, the largest numbers of cases were reported in the summer period. Analysis of the data on sting cases showed a difference due to the incidence of scorpion stings in the various seasons depending on the region climate, indicating that the scorpion activities are related to the climate. For example, scorpion activities increased during the spring and the summer in Southeastern Anatolia, Aegean and East Anatolia and increased during the summer and the autumn in Mediterranean and Central Anatolia.

The present analysis showed that Turkey have a high occurrence rate of scorpion stings $(24,261$ cases). In general, most of the sting cases were seen during the summer period in Turkey, especially in the Southeastern Anatolia (Sanlıurfa, Adıyaman, Mardin, Gaziantep, Batman), Mediterranean Sea (Antalya, Kahramanmaras, Icel, and Hatay), Aegean (Mugla, Aydın, Denizli), Central Anatolia (Konya, Kırıkkale, Nevsehir, Karaman, Nigde) and East Anatolia (Malatya, Igdır, Hakkari) regions, according to the analyses of geographical data of scorpion stings. These regions present scorpion species which are known as medically important. Scorpion stings are responsible for significant morbidity; therefore, our results suggest that scorpion stings are an important health problem in Turkey, especially in the Southeastern Anatolia, Mediterranean Sea and Aegean regions.

In conclusion, to decrease both scorpion stings and possible envenomations of humans, (a) the population should be aware of scorpions; (b) antivenom must be continuously supplied to the health centers of the regions which have high incidence of scorpion stings - the beginning of the scorpion activities in geographical regions 
must be considered for antivenom supplying; (c) medical professionals from risky regions should be informed about medically important scorpion species and their knowledge about scorpionism treatment should be kept up-to-date; (d) the children's careless behaviors such as walking barefoot, lifting stones and playing with scorpion nests can increase the number of scorpion stings; therefore, training brochures should be prepared and exhibited at schools.

\section{ACKNOWLEDGMENTS}

We wish to thank Karina Luiz Chamma for her valuable comments on this manuscript.

\section{REFERENCES}

1 ADIGUZEL S., OZKAN O., INCEOGLU B. Epidemiological and clinical characteristics of scorpionism in children in Sanliurfa, Turkey. Toxicon, 2007, 49, 875-0.

2 ADOLFO R., DE ROODT AR., GARCÍA SI., SALOMÓN OD., SEGRE L., DOLAB JA., FUNES RF., TITTO EH. Epidemiological and clinical aspects of scorpionism by Tityus trivittatus in Argentina. Toxicon, 2003, 41, 971-7.

3 AKCAY A., GURSES D., OZDEMIR A., KILIC I., ERGIN H. The Childhood poisoning in Denizli. J. Adnan Menderes Univ. Med. Fac., 2005, 6, $15-9$.

4 ALTINKAYNAK S., ERTEKIN V., ALP H. Scorpion envenomation in children. Turk. Arch. Ped., 2002, 37, 48-54.

5 BALOZET L. Scorpionism in the Old World. In: BÜCHERL W., BUCKLEY EE. Eds. Venomous animals and their venoms. 3. Venomous invertebrates. New York: Academic Press, 1971: 349-71.

6 BAWASKAR HS. Management of severe scorpion sting at rural settings: what is the role of scorpion antivenom? J. Venom. Anim. Toxins incl. Trop. Dis., 2005, 11, 37.

7 BERGMAN NJ. Clinical description of Parabuthus transvaalicus scorpionism in Zimbabwe. Toxicon, 1997, 35, 759-71.

8 BUCARETCHI F., BARACAT EC., NOGUEIRA RJ., CHAVES A., ZAMBRONE FA., FONSECA MR., TOURINHO FS. A comparative study of severe scorpion envenomation in children caused by Tityus bahiensis and Tityus serrulatus. Rev. Inst. Med. Trop. São Paulo, 1995, 37, 331-6. 
9 CHOWELL G., DIAZ-DUENAS P., BUSTOS-SALDANA R., ALEMAN-MIRELES A., FET V. Epidemiological and clinical characteristics of scorpionism in Colima, Mexico (2000-2001). Toxicon, 2006, 47, 753-8.

10 DAYAR E., GÖRSEL G., DURSUN O., KARDELEN F., UĞUZ A. Akrep sokması sonrası ciddi aritmi ve miyokard iskemisi: Olgu sunumu (Poster presentation). 50. Milli Pediatri Kongresi. 2006, 8-12 Kasım. World of Wonders / Kremlin Palace, Aksu, Antalya. Available from http://www.millipediatri.org.tr/bildiriler/PP-415.htm

11 DEHESA-DAVILA M., POSSANI LD. Scorpionism and serotherapy in Mexico. Toxicon, 1994, 32, 1015-8.

12 DEMIRSOY A., DURMUŞ Y., AKBULUT A. Türkiye scorpiones (akrep) faunasının sistematik ve biyolojik yönden incelenmesi. Proje No: 1998 K 1001 40. Çevre Bakanlığı Çevre Koruma Genel Müdürlüğü Hayvanları Koruma Dairesi Başkanlığı. 2001. Ankara.

13 DITTRICH K., POWER AP., SMITH NA. Scorpion sting syndrome - a ten-year experience. Ann. Saudi Med., 1995, 15, 148-55.

14 FARGHLY WMA., ALI FA. A clinical and neurophysiological study of scorpion envenomation in Assiut, Upper Egypt. Study of scorpion envenomation in Assiut, upper Egypt. Intern. J. Paediatric., 1999, 88, 290-4.

15 FET V., BRAUNWALDER ME. The scorpions (Arachnida: Scorpiones) of the Aegean area: current problems in taxonomy and biogeography. Belg. J. Zool., 2000, 130, 15-20.

16 GHALIM N., EL-HAFNY B., SEBTI F., HEIKEL J., LAZAR N., MOUSTANIR R., BENSLIMANE A. Scorpion envenomation and serotherapy in Morocco. Am. J. Trop. Med. Hyg., 2000, 62, 277-83.

17 HAMMOUDI-TRIKI D., FERQUELB E., ROBBE-VINCENT A., BONB C., CHOUMETB V., LARABA-DJEBARIA F. Epidemiological data, clinical admission gradation and biological quantification by ELISA of scorpion envenomations in Algeria: effect of immunotherapy. Trans. Rev. Soc. Trop. Med. Hyg., 2004, 98, 240 50.

18 HISHAM MA. Scorpion sting syndrome: epidemiology, clinical presentation and management of 2240 cases. East. Mediterr. Health J., 1997, 3, 82-99.

19 ISBISTER GK., GRAUDINS A., WHITE J., WARREL D. Antivenom treatment in Arachnidism. J. Toxicol. Clin. Toxicol., 2003, 41, 291-300. 
20 KARAKURT C., KOCAK G. Toxic myocarditis after scorpion envenomation: Case Report. J. Inonu Univ. Med. Fac., 2007,14, 61-3.

21 KARATAS A. Mesobuthus caucasicus (Nordmann, 1840) (Scorpiones: Buthidae) in Turkey. Euscorpius, 2005, 25, 1-9.

22 KARATAS A., GHARKHELOO MM. A contribution to the knowledge of Hottentotta saulcyi (Simon, 1880) (Scorpiones: Buthidae). Zool. Middle East, 2006, 38, 85-92.

23 KARATAS A., KARATAS AH. Mesobuthus eupeus (C.L. Koch, 1839) (Scorpiones: Buthidae) in Turkey. Euscorpius, 2003, 7, 1-6.

24 KEKEC Z., AVSAROGULLARI L., IKIZCELI I., KURTOGLU S., SOZUER E. Analysis of the patients who applied to Erciyes University Medical School Department the Emergency Medicine due to animal poisoning. Turk. J. Emerg. Med., 2003, 3, 45-8.

25 MAHADEVAN S. Scorpion sting. Indian Ped., 2000, 37, 504-14.

26 MOCAN H., MOCAN MZ., KAYNAR K. Haemolytic-ureamic syndrome following a scorpion sting. Nephrol. Dial. Transplant., 1998, 13, 2639-40.

27 MULLER GJ. Scorpionism in South Africa. A report of 42 serious scorpion envenomations. S. Afr. Med. J., 1993, 83, 405-11.

28 OSNAYA-ROMERO N., MEDINA-HERNANDEZ TJ., FLORES-HERNANDEZ SS., LEON-ROJAS G. Clinical symptoms observed in children envenomed by scorpion stings, at the Children's Hospital from the state of Morelos, Mexico. Toxicon, 2001, $39,781-5$.

29 OZKAN N. Mesobuthus gibbosus türü akrep zehrinin farelerde minimal lethal dozunun (MLD50) saptanması E.U Institute of Health Sciences, 1992, Izmir-Turkey.

30 OZKAN O., ADIGUZEL S., YAKISTIRAN S., CESARETLI Y., ORMAN M., KARAER KZ. Androctonus crassicauda (Olivier 1807) scorpionism in the Sanliurfa Provinces of Turkey. Acta Parasitol. Turcica, 2006, 30, 239-45.

31 OZKAN O., KARAER Z. The scorpions in Turkey. Turk. Hig. Deney. Biyol. Derg., 2003, 60, 55-62.

32 OZKAN O., KAT I. Mesobuthus eupeus scorpionism in Sanliurfa region of Turkey. J. Venom. Anim. Toxins incl. Trop. Dis., 2005, 11, 479-91.

33 PARDAL PP., CASTRO LC., JENNINGS E., PARDAL JS., MONTEIRO MR. Epidemiological and clinical aspects of scorpion envenomation in the region of Santarém, Pará, Brasil. Rev. Soc. Bras. Med. Trop., 2003, 36, 349-53. 
34 RADMANESH M. Androctonus crassicauda sting and its clinical study in Iran. J. Trop. Med. Hyg., 1990, 93, 323-6.

35 SADEGHIAN $\mathrm{H}$. Transient ophthalmoplegia following envenomation by the scorpion Mesobuthus eupeus. Neurology, 2003, 2, 346-7.

36 SILVA RML., AMORIM AM., BRAZIL TK. Envenomation by Tityus stigmurus (Scorpiones; Buthidae) in Bahia, Brazil. Rev. Soc. Bras. Med. Trop., 2000, 33, 23945.

37 SOKER M., HASPOLAT K. Güneydoğu ve Anadolu bölgesinde çocuklarda akrep sokması: 64-vakanın değerlendirilmesi. Çocuk Sağı̆ğı ve Hastalıkları Dergisi, 2000, 43(1), 43-50.

38 SUZEK H., EVREN H., YAPAR S. Mugla Devlet Hastanesi acil servisine başvuran akrep ve yılan sokma vakalarının incelenmesi. Uluslararası Insan Bilimleri Dergisi (ISSN: 1303-5134). 2004, 1, 1-4. Available from http://www.insanbilimleri.com/ojs/index.php/uib/article/viewPDFInterstitial/130/130.

39 THEAKSTON RDG., WARRELL DA, GRIFFITHS E. Report of a WHO workshop on the standardization and control of antivenom. Toxicon, 2003, 20, 1-17.

40 TOULOUN O., SLIMANI T., BOUMEZZOUGH A. Epidemiological survey of scorpion envenomation in Southwestern Morocco. J. Venom. Anim. Toxins incl. Trop. Dis., 2001, 7, 199-218.

$41 \mathrm{VACHON} \mathrm{M.} \mathrm{A} \mathrm{propes} \mathrm{de} \mathrm{quelques} \mathrm{Scorpions} \mathrm{de} \mathrm{Turquie} \mathrm{collectés} \mathrm{par} \mathrm{M.} \mathrm{le}$ Professeur Dr. Curt Kosswig. Prof. Kosswig tarafından Türkiye'de toplanan akrepler hakkında, I.Ü. Fen Fak. Mec., 1951, 16, 341-4.

42 VACHON M. Liste des scorpions connus en Egypte, Arabie, Israël, Liban, Syrie, Jordanie, Turquie, Irak, Iran. Toxicon, 1966, 4, 209-18.

43 VAN MOPPES NM., KUNST MW. A scorpion sting in the Netherlands. Ned. Tijdschr Gneneesk, 1994, 138, 2590-1. 